\title{
Annual variation in sensory characteristics of seventeen apple cultivars
}

\author{
Seppä Laila ${ }^{1,2}$, Tahvonen Risto ${ }^{3}$, Tuorila Hely ${ }^{1}$ \\ ${ }^{1}$ Department of Food and Environmental Sciences, P.O.Box 66, FI - 00014 University of Helsinki, Finland, \\ ${ }^{2}$ Current address: Sensory Analysis Center, Kansas State University, 1310 Research Park Drive, Manhattan, KS 66502, USA \\ ${ }^{3}$ Natural Resources Institute (LUKE) Finland, Horticultural division, Toivonlinnantie 518, FI - 21500 Piikkiö, Finland \\ e-mail: laila.seppa@helsinki.fi
}

\begin{abstract}
Sensory characteristics of 17 apple cultivars commonly grown in Finland were compared over three harvest years (2009-2011). Descriptive analysis with a trained panel $(n=11-14)$ comprised 17 attributes rated from 0 ('not at all') to 10 ('very'): four appearance (green, red, area of red colour, skin waxiness), three odour (intense, grassy, fruity), five texture (hard, crispy, mealy, juicy, tough peel), and five flavour (intense, sour, sweet, astringent, diverse) attributes. Ratedintensities differed between the harvest years but their magnitude and direction of change varied according to the cultivar. Odour and flavour ratings tended to be higher in 2009 than in 2010 and 2011. The summer 2009 was fairly normal, while summer 2010 was hot and dry, and summer 2011 hot and humid. These climate may explain some of the differences between the first and the two subsequent years. Late season cultivars tended to be relatively stable against annual effects.
\end{abstract}

Key words: apple, cultivar, descriptive analysis, sensory evaluation, harvest year

\section{Introduction}

The cultivation of apples (Malus domestica Borkh) is increasing in Northern Europe, although the climate and high costs restrict production (Tahvonen 2007, Lehtonen 2015). In Finland, apple cultivation is important for rural economy. The annual crop has doubled since late 1990s, being now around 5 million kg (LUKE 2015a). Domestic apples are well liked and appreciated, because they are perceived as natural, fresh and clean, and have a low content of toxic residues (Malkki 2007, Seppä 2014).

The grouping of domestic apple cultivars as summer, autumn and winter, or early, mid and late season cultivars, respectively, is based on the degree day (DD5), cumulative base temperature over $5{ }^{\circ} \mathrm{C}$, requirements for harvest maturity (Tahvonen 2007, Kaukoranta et al. 2010). Early season cultivars are important in Finnish tradition, while late season cultivars are commercially more important, as they usually have longer storage life. Seppä et al. (2013a) showed that some late season cultivars maintain eating quality beyond the end of the harvest year even without controlled atmosphere storage.

The global warming is already affecting plant phenology and cultivation, but effects differ depending on the plant and geographical area (Kaukoranta et al. 2010, Sugiura et al. 2013, Lehtonen 2015). With increasing level of DD5, the limit of commercial apple cultivation is moving northwards and the trend is estimated to continue (Kaukoranta etal. 2010, Finnish Meteorological Institute 2014). Domestic late season cultivars are likely to benefit the most. Currently, the level of DD5 reached in most years in southern Finland is between 1300 and 1400, but may be as high as 1600 . The effects of climate change on harvest quality are hard to estimate, as the influence of non-climatic factors, such as horticultural and technological improvements can be substantial (Sugiura et al. 2013). For example, rootstock, training system and orchard density affect the availability of light and consequently, the rate of photosynthesis and the yield and its quality (Hampson et al. 2004, Thybo et al. 2005, Tahvonen 2007).

Caprio \& Quamme (1999), using apple production data collected during 72 years in British Columbia, Canada, showed that temperatures of $30{ }^{\circ} \mathrm{C}$ or over in mid-summer of the pre-harvest year reduced future flower formation. High temperatures in late summer of the harvest year were unfavourable to the apple yield due to increased respiration leading to reduced photosynthesis. In addition to the lessened yield, reduced photosynthesis may cause less flavonoids and other phenolic and bioactive compounds to be synthesised. The quantity of these compounds can vary manifold between cultivars and harvest years (Wolfe et al. 2003, Łata and Tomala 2007,Belviso et al. 2013 ). Sugiura et al. (2013) observed that anthocyanin level, responsible for the redness of apple peel, decreased in 'Fuji' apples, when temperature was over $25^{\circ} \mathrm{C}$. Some phenolic compounds, such as chlorogenic acid and phloridzin, had a significant annual effect over three study years (van der Sluis et al. 2001, Belviso et al. 2013). Decreased contents of phenolic and other bioactive compounds are likely to decrease the nutritional and flavour quality of the crop. 
The relative quantities of sugars change during advanced ripening, but depend also on the cultivar (Railio 2010, Bizjak et al. 2013, Corollaro 2014) and the harvest year (Bizjak et al. 2013). Sugiura et al. (2013) showed that acid concentration and firmness decreased significantly during a 40-year research period in different parts of Japan, alongside with increasing annual mean temperature. At the same time, soluble solids concentration increased by $0.20-0.28^{\circ}$ Brix per decade. These changes most probably affect the sensory quality and consequently, acceptability of apples, although the content of individual sugars or soluble solids concentration is not directly related to sweetness (Harker et al. 2002, Railio 2010, Corollaro et al. 2014).

In spite of the research findings mentioned above, little is known about the effect of the annual variation of weather on the sensory quality and thus, consumer quality of apples. The stability of the sensory characteristics of domestic apples in the market is important for the consumers (Malkki 2007, Seppä 2014). Even in commercial cultivation, the amount of harvested crop varies considerably yearly (LUKE 2015a), and most probably, so does the quality. In summary, changes in the sensory characteristics of apples over the years are caused by 1) immediate weather factors, 2) horticultural and technological improvements and practices, 3) climate change, and 4) their interactions.

The aim of the present study was to describe and quantify sensory characteristic of selected cultivars during a 3-year-period. Descriptive analysis was performed on 17 cultivars harvested in 2009, 2010 and 2011 in South-Western Finland and stored according to the standard horticultural practices. Evaluations were conducted when the apples had reached full ripeness and 2-3 weeks later to simulate average commercial maturity. The research questions were formulated as follows: 1) Does the harvest year have an effect, 2) are the effects cultivar-specific, and 3) are late season cultivars more stable in their sensory characteristics over the years than their early season counterparts.

\section{Materials and methods}

\section{Cultivars}

Seventeen apple cultivars, representing a wide range of traditional and new cultivars with distinct sensory properties (Seppä et al. 2012) were evaluated with generic descriptive analysis (GDA) as described by Lawless \& Heymann (2010) during three harvest years 2009-2011 as part of a larger project. The cultivars are listed in the ascending order of DD5 required for ripening of fruit in Table 1. Ten cultivars have been released by MTT (now LUKE, Natural Resources Institute Finland), already in production. 'Pirja' has one of the smallest DD5's among the apples in the world, less than 1000, and is ready for eating at the end of July. Due to the evaluation schedules, it was not evaluated in 2010. 'Y9330' is a selection by MTT, and was not yet in full scale production in 2009-2011.The rest of the cultivars originate from Sweden, England and Canada (Tahvonen 2007). 'Lobo' was introduced over 100 years ago. It has long been the most popular commercial cultivar, but now its cultivation area is declining. 'Amorosa' is a red variant of 'Aroma' and they are gaining popularity among the producers. In 2009 both were evaluated, while in 2010 and 2011, 'Aroma' and 'Amorosa' were evaluated, respectively. In this project, a cultivar is considered domestic, when apples are grown and harvested in Finland, although the cultivar strain itself may be of non-domestic origin.

Apples were harvested during August - September of each year in the orchards of MTT research station in Kaarina (Piikkiö, location $60^{\circ} 23^{\prime} \mathrm{N} 22^{\circ} 33^{\prime} \mathrm{E}$ ), South-Western Finland, and surrounding areas, and stored in the cold storage of the orchards $\left(+3^{\circ} \mathrm{C}\right.$, relative humidity $80-92 \%$, normal atmosphere). General weather conditions in the harvest area are presented in Table 2 (Finnish Meteorological Institute 2014, 2015).

Rainfall in 2010 was exceptionally high in May $(75.8 \mathrm{~mm}, 204 \%$ of the mean 1981-2009) and September (100.8 $\mathrm{mm}, 172 \%$ of the mean 1981-2009) but the rest of the summer was hot and dry. In 2011, the summer was warm as well, but rainfall was above average. As late season cultivars are usually harvested by the mid-September, they benefit from warm autumns, such as is in 2009 and 2011. It is beneficial to the next year's crop if at least 100 DD5 degrees accumulate after harvest, to prepare the trees for winter (Tahvonen 2007, Kaukoranta et al 2010).

The maturation of cultivars was monitored using horticultural methods such as starch iodine test, visual inspection and brix measurements (Brookfield et al. 1997, Tahvonen 2007, Seppä et al. 2012). Storage conditions were typical of Finnish apple production, as the availability of controlled atmosphere storage is very limited. Before each evaluation, the apples were transported in batches to the cold store $\left(+4{ }^{\circ} \mathrm{C}\right.$, normal atmosphere) at the Department of Food and Environmental Sciences, University of Helsinki. Practical arrangements, such as the number and type of cultivars in a batch, differed slightly depending on the year. Cultivars were evaluated when they had reached commercial maturity (storage point A) and 2-3 weeks later (storage point B). 
L. Seppä et al. (2016) 25: 202-215

Table 1. Apple cultivars included in the study with their breed, characteristics and DD5, the requirement for cumulative base temperature over $5^{\circ} \mathrm{C}$ during growing season (Tahvonen 2007, Krannila and Paalo 2008)

\begin{tabular}{|c|c|c|c|c|c|c|c|}
\hline $\begin{array}{l}\text { Seasonal } \\
\text { category }\end{array}$ & Cultivar & DD5 & Parentage & $\begin{array}{l}\text { Origin of } \\
\text { cultivar }\end{array}$ & $\begin{array}{l}\text { Available in } \\
\text { Finland since }\end{array}$ & $\begin{array}{l}\text { Maturation in } \\
\text { storage }\end{array}$ & $\begin{array}{c}\text { Storage } \\
\text { life/ } \\
\text { weeks }\end{array}$ \\
\hline \multirow[t]{3}{*}{ Summer } & Pirja & 972 & Huvitus x Melba & LUKE $^{\text {a) }}$ & 1980 & no & 2 \\
\hline & Vuokko & 1100 & Melba $x$ Huvitus & LUKE & 1999 & no & $4-6$ \\
\hline & Petteri & 1120 & Lobo $x$ Huvitus & LUKE & 2003 & no & $4-5$ \\
\hline \multirow[t]{7}{*}{ Autumn } & Big Melba & 1140 & Melba x Huvitus & LUKE & 2003 & 2 weeks & $3-4$ \\
\hline & Samo & 1159 & Melba x Huvitus & LUKE & 1981 & 2 weeks & $1-2$ \\
\hline & Heta & 1200 & Lobo $x$ Huvitus & LUKE & 1996 & 2 weeks & $4-6$ \\
\hline & Pekka & 1230 & Lobo $x$ Huvitus & LUKE & & 2 weeks & 4 \\
\hline & Tobias & 1235 & Lobo $x$ Huvitus & LUKE & 2003 & 2 weeks & $6-8$ \\
\hline & Discovery & 1235 & Worcester-Pearmain & England & 1964 & yes & 6 \\
\hline & Summerred & 1260 & Summerland* & Canada & 1964 & yes & 8 \\
\hline \multirow[t]{7}{*}{ Winter } & Red Atlas & 1250 & Winter St.Lawrence* & Canada & $\mathrm{n} / \mathrm{a}$ & yes & $4-6$ \\
\hline & Eva-Lotta & 1260 & Cortland x James Grieve & Sweden & 1992 & yes & 8 \\
\hline & $\begin{array}{l}\text { Åkerö } \\
\text { Hassel }\end{array}$ & 1260 & Åkerö & Sweden & $\mathrm{n} / \mathrm{a}$ & 2-4 weeks & 8 \\
\hline & Konsta & 1264 & Lobo x Antonovka & LUKE & 1997 & 4 weeks & 4 \\
\hline & Lobo & 1302 & Maclntosh * & Canada & 1898 & 3-4 weeks & 8 \\
\hline & $\begin{array}{l}\text { Aroma \& } \\
\text { Amorosa }\end{array}$ & 1338 & Ingrid Marie x Filippa & Sweden & $\mathrm{n} / \mathrm{a}$ & 4 weeks & 6 \\
\hline & Y9330 & 1350 & Wealthy * & LUKE & no & long & $8-12$ \\
\hline
\end{tabular}

* = open pollination; $\mathrm{n} / \mathrm{a}$ ) = data not available; no = not commercially available in 2009-2011; a = LUKE was formerly MTT (Agrifood Research Finland)

Table 2. Main weather indicators between May and September of 2009, 2010 and 2011. Data on temperature and rainfall, and deviation from their means (dev. ftm) of 1981-2010 measured in Salo, location 60 $37^{\prime} \mathrm{N} 23^{\circ} 11^{\prime} \mathrm{E}$ (Finnish Meteorological Institute 2014). Monthly and cumulative base temperatures during growing season (DD5) collected in Kaarina, Yltöinen, location $60^{\circ} 39^{\prime} \mathrm{N} 22^{\circ} 55^{\prime} \mathrm{E}$ (Luke 2015b)

\begin{tabular}{|c|c|c|c|c|c|c|c|}
\hline \multirow[t]{2}{*}{ Year } & \multirow[t]{2}{*}{ Month } & \multicolumn{2}{|c|}{ Temperature ${ }^{\circ} \mathrm{C}$} & \multicolumn{2}{|c|}{ Rainfall } & \multicolumn{2}{|c|}{ DD5 } \\
\hline & & Mean & $\begin{array}{l}\text { Dev. ftm } \\
1981-2010\end{array}$ & $\begin{array}{c}\text { Mean } \\
\mathrm{mm}\end{array}$ & $\begin{array}{l}\text { Dev. ftm (\%) } \\
1981-2010\end{array}$ & monthly & cumulative \\
\hline \multirow[t]{5}{*}{2009} & May & 11.2 & +0.8 & 23.0 & 62 & 167 & 184 \\
\hline & June & 13.8 & -0.9 & 67.0 & 118 & 256 & 441 \\
\hline & July & 16.4 & -1.0 & 55.9 & 78 & 355 & 796 \\
\hline & August & 15.8 & +0.1 & 64.7 & 76 & 340 & 1136 \\
\hline & September & 12.4 & +1.7 & 48.8 & 83 & 232 & 1368 \\
\hline \multirow[t]{5}{*}{2010} & May & 11.7 & +1.3 & 75.8 & 204 & 194 & 197 \\
\hline & June & 14.5 & -0.2 & 49.3 & 87 & 272 & 470 \\
\hline & July & 21.5 & +4.1 & 28.0 & 39 & 492 & 961 \\
\hline & August & 17.0 & +1.3 & 66.2 & 78 & 374 & 1335 \\
\hline & September & 11.0 & +0.3 & 100.8 & 172 & 189 & 1524 \\
\hline \multirow[t]{5}{*}{2011} & May & 10.0 & -0.4 & 39.1 & 105 & 136 & 161 \\
\hline & June & 17.2 & +2.5 & 66.5 & 117 & 354 & 515 \\
\hline & July & 20.0 & +2.6 & 143.6 & 199 & 454 & 969 \\
\hline & August & 16.2 & +0.5 & 88.4 & 104 & 351 & 1319 \\
\hline & September & 12.6 & +1.9 & 88.3 & 151 & 236 & 1555 \\
\hline
\end{tabular}


Profile results were calculated as the mean of the ratings at A and B. In 2009 and 2011, early season cultivars were evaluated only once (Table 3).

Table 3. Data collection settings for the cultivars with the number of storage points (maturity), size of the panel (n), and replicates

\begin{tabular}{|c|c|c|c|c|c|}
\hline Year / season & Cultivars (n) & Maturity & Panel (n) & Replicates & Cultivars studied \\
\hline 2009 / early & 3 & 1 & 12 & 4 & Pirja, Vuokko, Petteri \\
\hline 2009 / mid & 7 & 2 & 12 & 4 & $\begin{array}{l}\text { Big Melba, Samo, Heta, Pekka, Discovery, Tobias, } \\
\text { Summerred }\end{array}$ \\
\hline 2009 / late & 8 & 2 & 11 & 2 & $\begin{array}{l}\text { Red Atlas, Eva-Lotta, Åkerö Hassel, Konsta, Lobo, } \\
\text { Aroma, Amorosa, Y9330 }\end{array}$ \\
\hline 2010 / early, mid \& late & 16 & 2 & 14 & 2 & All except Pirja and Amorosa \\
\hline 2011 / early & 3 & 1 & 13 & 2 & Pirja, Vuokko, Petteri \\
\hline 2011 / mid \& late & 14 & 2 & 13 & 2 & $\begin{array}{l}\text { Big Melba, Samo, Heta, Pekka, Discovery, Tobias, } \\
\text { Summerred, Red Atlas, Eva-Lotta, Åkerö Hassel, } \\
\text { Konsta, Lobo, Amorosa, Y9330 }\end{array}$ \\
\hline
\end{tabular}

\section{The panel}

Panel members ( $n=11-14$ depending on the year and season, aged $22-57$ years, Table 3 ) were volunteers among the students and employees at the Department. They were familiar with the descriptive analysis method, but none of them had evaluated apples before entering the panel. Three of the panellists participated in all three years and six participated in two years.

The study protocol followed the ethical guidelines of the sensory laboratory, approved by the ethical committee of the Viikki Campus, University of Helsinki. A written informed consent was obtained from each participant before they entered the training phase.

\section{The lexicon}

Development of the lexicon, including reference standards and other information representing extreme ends of each attribute, was initiated in 2009 ( $1^{\text {st }}$ year of data collection) with summer cultivars (including 'Pirja', 'Vuokko', 'Transparente Blanche', 'Petteri') concurrently with panel training. After familiarising themselves with the cultivars in home use and collecting suggestions for the attributes, the panel met in three two-hour-sessions and agreed on 20 attributes and their references (Seppä et al. 2012). Likewise, in the two following years, training started with the early season apples.

In the $2^{\text {nd }}$ year (2010), the lexicon was fine tuned to contain 17 attributes (Table 4): four related to texture, three to odour (aroma), five to texture and five to flavour. Two of the flavour attributes measured basic tastes, sour and sweet. Astringent flavour is a tactile sensation due to chemical stimuli such as tannins and other phenolic compounds (Lawless and Heymann 2010). These sensations are described as mouth drying, tickling or tightening of the mucosa. 
Table 4. The attributes and references used in descriptive analysis in 2009-2011 (Seppä et al. 2012, Seppä et al. 2013a)

\begin{tabular}{|c|c|c|}
\hline ATTRIBUTE & & STANDARDS \\
\hline in English & in Finnish & \\
\hline Appearance & Ulkonäkö & \\
\hline green & vihreä & paints NCS S0520-G70Y < NCS S2070-G30Ya) \\
\hline red & punainen & paints NCS S0530-Y70R < NCS S4050-Y90R a) \\
\hline area of red colour & punaisen määrä & estimation of percentage \\
\hline skin waxiness & kuoren vahaisuus & compared to the waxiness of $c v$. Transparente blanche \\
\hline Odour & Haju & \\
\hline intense & voimakas & na \\
\hline grassy & ruohomainen & $<$ fresh parsley leaves with fresh apple slices ${ }^{\text {b) }}$ \\
\hline fruity & hedelmäinen & $<$ canned fruit cocktail in juice \\
\hline Texture & Rakenne & \\
\hline hard & kova & boiled carrot $<$ raw carrot \\
\hline crispy & rapea & boiled carrot < celery \\
\hline mealy & jauhoinen & boiled carrot $<$ boiled mealy Rosamunda potato \\
\hline juicy & mehukas & boiled mealy Rosamunda potato $<$ mature pear \\
\hline tough peel & kuoren sitkeys & na \\
\hline Flavour, taste & Maku & \\
\hline intense & voimakas & na \\
\hline sour & hapan & $<0.5 \%$ L(-)-malic acid in Muksu apple jam (sour) c) \\
\hline sweet & makea & < C24 10 \% sucrose in Muksu apple jam (sweet) ${ }^{c}$ ) \\
\hline astringent & astringoiva & $<0.15 \%$ tannic acid in Muksu apple jam (astringent) ${ }^{c}$ \\
\hline diverse & monipuolinen & na \\
\hline
\end{tabular}

$\mathrm{a}=$ Teknos paint catalogue, www.teknos.fi and www.teknos.co.uk/?pagelD=H2892; $b=\ln 2009$, the reference was cis-3-hexen1-ol (15 $\mu \mathrm{l} 10 \mathrm{~g}^{-1}$ paraffin wax); c = "Muksu" is a commercial, unsweetened apple jam for babys. In 2009, malic acid and sucrose were mixed in water, tannic acid in unsweetened apple juice; na = no reference available. Guidelines for evaluation were set by discussion.

\section{The procedure}

Apples were evaluated following the general principles of GDA (Lawless and Heymann 2010). The attribute intensities were rated for intensity on a graphic, unstructured scale ranging from 'not at all' (0) to 'very' (10) for each attribute, except for the area of red for which the range was 0-100\% (converted to $0-10$ ). The evaluations were performed at room temperature at individual speed using Fizz sensory analysis software (versions 2.20-2.47 Biosystems, Couternon, France). Mouth was rinsed with tap water between the samples. Each evaluation was made twice, except early and mid-season cultivars in 2009 which were made four times. The samples in each session were randomised (Latin square) and coded with three-digit numbers with each replicate having different codes.

The number of samples varied from 3 to 5 in a session, depending on the harvesting schedule and maturation of the apples. Before the evaluation of each batch, an additional training session was arranged, where the characteristics of the apples in the new batch were discussed and attributes and their references were compared with these characteristics. The attribute descriptions and reference standards were available throughout the evaluations. For new panel members, training started with orientation sessions, where GDA as well as the attributes, references and evaluation methods were discussed. After the orientation sessions, the whole panel participated in 6 hours of training. The first year's training resembled "consensus training" (Lawless and Heymann 2010), while the next two times, training was a combination of "consensus training" and "ballot training", where the lexicon is given by the panel leader. 
The appearance attributes were evaluated at the beginning of each session from a set of ten apples per cultivar in a separate space under white light. Next, odour, texture and flavour attributes were evaluated in the order presented in Table 4 in individual booths under red light to disguise the differences in the appearance (Karlsen et al. 1999). At this point, a sample consisted of two unpeeled, whole apples, to avoid discolouration, off-flavours and tacky surface caused by the peeling and cutting (Seppä et al. 2012). The panellists used the second apple, if the first apple was not enough for rating all attributes. This was particularly relevant for small apples weighting less than $70 \mathrm{~g}$. Each panellist had a plastic cutting board and a knife for cutting appropriate slices during evaluation. The odour attributes where evaluated from the freshly cut surface. Attribute hard was evaluated as the force required for cutting the apple. Other textural attributes were evaluated while masticating: crispiness by biting with front teeth, mealiness as the amount of soft, dry residue after continued chewing. Juiciness was estimated as the quantity of tasty liquid during chewing.

\section{Statistical analysis}

To assess the differences between the cultivars and harvest years, three-way analysis of variance was carried out for each attribute. The effect of cultivar (17), harvest year (3) and replicate (4 for early and mid-season cultivars in 2009, 2 for all other cultivars) on the attributes and their interactions were studied at the significance level $p=0.05$. Tukey's HSD test was used for multiple comparisons of the cultivars and harvest years. Attributes were studied with Pearson's correlations.

To help in narrowing down the number of attributes, factor analysis (maximum likelihood, varimax rotation) was used to find out which of them were the most significant in determining the sensory space of the cultivars. Attributes were selected based on their loadings on the factors and communalities. Communality of a variable indicates the proportion of variation in the variable explained by the factors (Nummenmaa 2011). Thus, variables with high communality are well represented in the factor space, while variables with low values do not fit well with the factor solution.

Principal component analysis (PCA) was performed to visualise the distinctive characteristics of the cultivars with Unscrambler X 10.1 (Camo SA, Trondheim, Norway). SPSS was used in other statistical analyses (version 23.0.0.2, IBM SPSS Statistics).

\section{Results}

The 17 cultivars evaluated in the study varied greatly in their sensory characteristics. A preliminary analysis showed that the intensities of all attributes differed between the cultivars, and all except mealiness between the harvest years (Suppl. Table S1). In addition, interaction cultivar by year was significant for all attributes, indicating that attribute intensities over years varied depending on the cultivar. Effect of replicate was small (F-ratios between 0.2 and 1.6) as well as interactions with replicates, indicating high reliability of sensory measurements.

The highest correlations were between attributes intense and fruity odours (0.536), sour and astringent flavours (0.595) and between intense and sweet (0.571) flavours (Suppl. Table S2). Correlations of colour attributes with odour, texture and flavour attributes were low, indicating that cultivar colour did not affect the evaluation process of other attributes.

\section{Sensory dimensions}

We used factor analysis to reduce the number of attributes and to reveal which were the most significant in defining the sensory space of the cultivars over the years (Table 5). The model with four factors (F1-F4) explained $43.3 \%$ of the variance.

F1 consisted of intense and fruity odours as well as intense, diverse and sweet flavours and was accordingly named "Sweet". Of the appearance attributes, red colour and area of red had strong loadings and F2 was thus named "Red". Similarly, F3 was named "Crispy" as crispy texture had a high loading (0.95). Hard, juicy and mealy had also considerable loadings in F3, the last attribute negative (-0.50). F4, "Sour", had intense, sour and astringent flavours as positive loadings and sweet flavour as a negative loading. Three attributes, juicy texture and intense and sweet flavours, loaded on two factors. Attributes with both strong loadings and strong communalities (bolded in Table 5) were used in further analyses, except that only one red descriptor was utilised (area of red), to avoid overstressing red colour, as their correlation was high (0.797). 
Table 5. Factor loadings (F1-F4) and communalities of the attributes evaluated in harvest years 2009-2011. Loadings of \pm 0.3 or stronger are marked with bold.

\begin{tabular}{|c|c|c|c|c|c|c|}
\hline \multirow{2}{*}{ Attributes } & & \multicolumn{4}{|c|}{ Factor loadings } & \multirow[t]{2}{*}{ Communalities } \\
\hline & & F1 Sweet & F2 Red & F3 Crispy & F4 Sour & \\
\hline \multirow[t]{4}{*}{ Appearance } & green & -0.03 & -0.33 & 0.01 & w 0.08 & 0.12 \\
\hline & red & 0.14 & 0.80 & 0.08 & -0.08 & 0.68 \\
\hline & red area & 0.12 & 0.95 & 0.12 & -0.10 & 0.94 \\
\hline & waxy & -0.07 & 0.21 & -0.10 & -0.04 & 0.06 \\
\hline \multirow[t]{3}{*}{ Odour } & intense & 0.45 & -0.03 & 0.09 & 0.12 & 0.23 \\
\hline & grassy & 0.07 & -0.14 & -0.05 & 0.27 & 0.10 \\
\hline & fruity & 0.55 & 0.08 & 0.04 & 0.05 & 0.31 \\
\hline \multirow[t]{5}{*}{ Texture } & hard & 0.20 & -0.01 & 0.43 & 0.05 & 0.22 \\
\hline & crispy & 0.11 & -0.04 & 0.95 & 0.07 & 0.91 \\
\hline & mealy & 0.09 & -0.00 & -0.50 & -0.03 & 0.26 \\
\hline & juicy & 0.36 & -0.07 & 0.40 & 0.10 & 0.31 \\
\hline & tough peel & 0.16 & 0.05 & 0.29 & -0.00 & 0.11 \\
\hline \multirow[t]{5}{*}{ Flavour } & intense & 0.50 & -0.01 & 0.26 & 0.43 & 0.51 \\
\hline & sour & -0.07 & -0.11 & 0.18 & 0.98 & 0.99 \\
\hline & sweet & 0.74 & 0.11 & 0.04 & -0.30 & 0.65 \\
\hline & astringent & 0.07 & -0.08 & 0.07 & 0.59 & 0.37 \\
\hline & diverse & 0.74 & 0.03 & 0.18 & 0.09 & 0.59 \\
\hline \multicolumn{2}{|c|}{ Variance explained \% (rotated solution) } & 12.45 & 10.42 & 10.32 & 10.09 & \\
\hline
\end{tabular}

\section{Cultivar profiles}

Year-to-year fluctuations were observed in most sensory attributes, but their magnitude and pattern depend on the cultivar (Suppl. Table S3). For example, 'Pekka', 'Discovery' and 'Eva-Lotta' were sweeter and crispier in the first year (2009) than in the following two years, but their basic characteristics remained the same: 'Pekka' was mealy with high sweetness and low sourness, and 'Discovery' and 'Eva-Lotta' were crispy and sweet with some sourness.

The general trend was that the intensities of fruity odour and flavour attributes were higher in 2009 than in the two other harvest years $(2010,2011)$. Yearly fluctuation was most often seen in crispiness and astringent flavour (13 cultivars for both attributes). Late season cultivars 'Aroma'/'Amorosa', 'Lobo', 'Eva-Lotta' and 'Åkerö Hassel' and early season cultivar 'Big Melba' were fairly resistant to annual effects. Standard deviations were typical for heterogeneous samples such as fruits, in most cases between 1.2 and 2.5.

In the following, cultivars are presented under three subheadings. First, the results of eight crosses between 'Huvitus', 'Melba' and 'Lobo' are presented, all of which are early and mid season cultivars. Then follow the results of 'Aroma' and 'Amorosa' and lastly, eight mid and late season cultivars.

\section{Profiles of crosses by 'Huvitus', 'Melba' and 'Lobo'}

Of the 17 cultivars studied, four were cultivars originating from 'Huvitus' and 'Melba' and four from 'Lobo' x 'Huvitus' (see Table 1). The cultivars from 'Huvitus' and 'Melba' had only a small year effect in the area of red colour and fruity odour (Fig. 1). Most of the cultivars presented in Fig. 1 had higher sweetness and sourness in 2009 than in either 2010 or 2011. Likewise in most cases, texture was crispier and juicier and less mealy in 2009 than in the following years. 'Big Melba' (Jättimelba in Finnish) had a year effect only in mealiness and in some flavour attributes. 


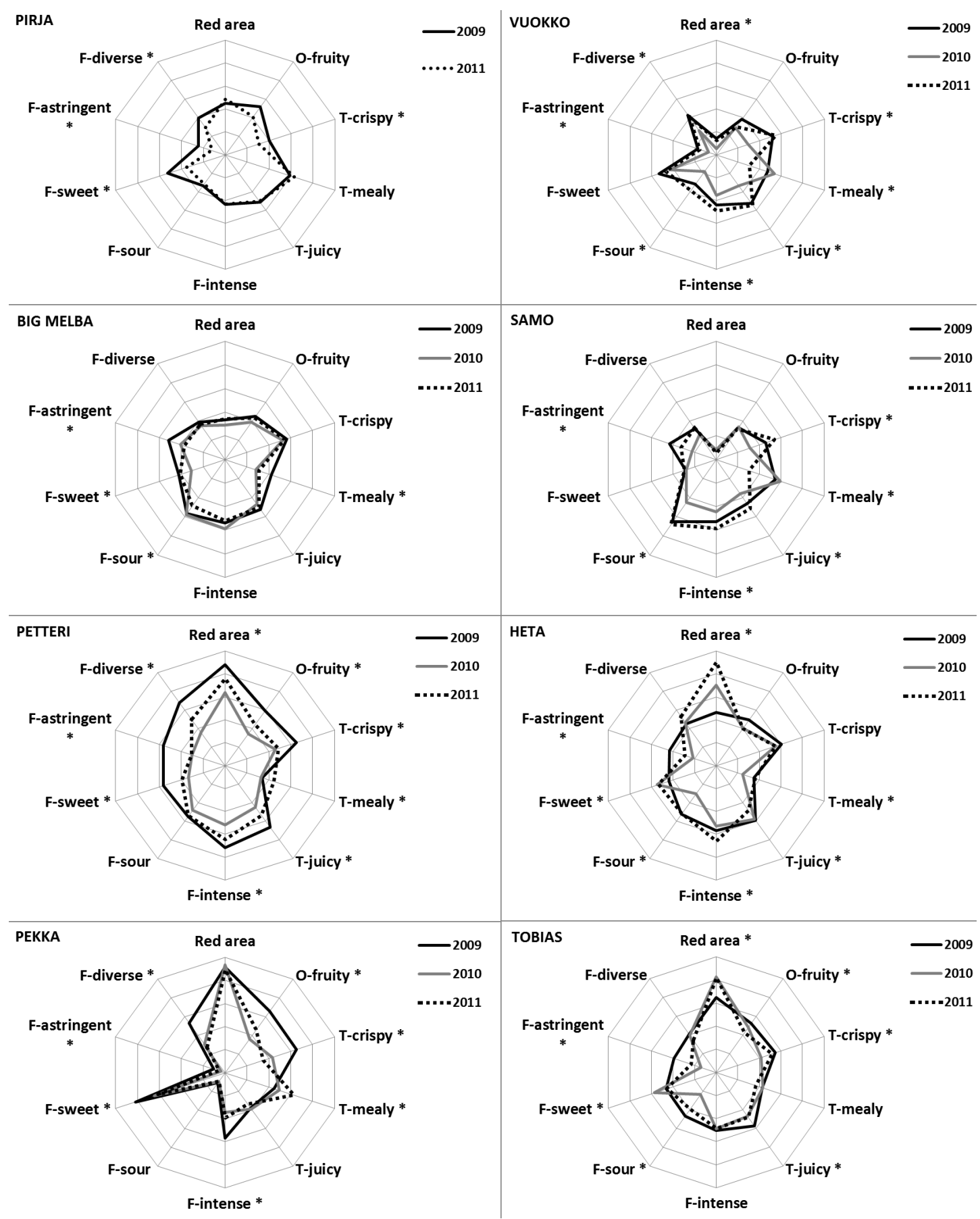

Fig. 1. Profiles of the cultivars originating from crosses of 'Huvitus', 'Melba' and 'Lobo' over three harvest years 2009, 2010 and 2011. Prefix O, T or F before an attribute name denote texture, odour and flavour, respectively. ${ }^{*} p<0.05$

\section{Profiles of Aroma and Amorosa}

The profile graph of the cultivars 'Aroma' and 'Amorosa' shows that they were quite similar during the three years (Fig. 2). Both were crispy and medium sweet and medium sour. The intensity of sweetness and sourness appears to have been slightly higher in 2009 than during the two following years. Although 'Amorosa' is a red variant of 'Aroma', 'Aroma' had larger red area in 2010 than either 'Aroma' in 2009 or 'Amorosa' in 2009 or 2011. 


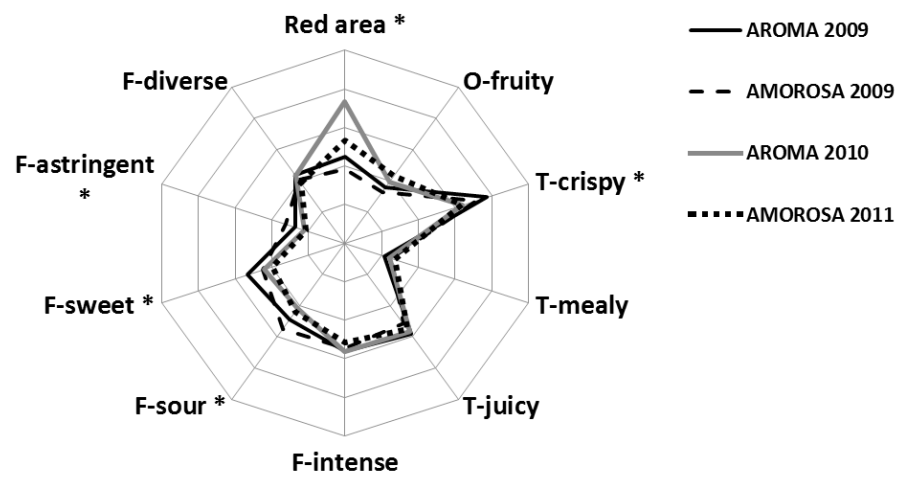

Fig. 2. Profiles of 'Aroma' and 'Amorosa' over three harvest years 2009, 2010 and 2011. Prefix O, T or F before an attribute name denote texture, odour and flavour, respectively; ${ }^{*} p<0.05$

\section{Profiles of other mid and late cultivars}

Seven cultivars in the study were of non-domestic origin: colour variants 'Aroma' and 'Amorosa' and further six mid and late season cultivars presented in Fig. 3 ('Discovery', 'Summerred', 'Red Atlas', 'Eva-Lotta', 'Åkerö Hassel' and 'Lobo'). Late season cultivars of domestic origin in Figure 3 were 'Konsta', a cross 'Lobo' x 'Antonovka', and new selection 'Y9330', an open pollinated seedling in MTT Piikkiö orchards.

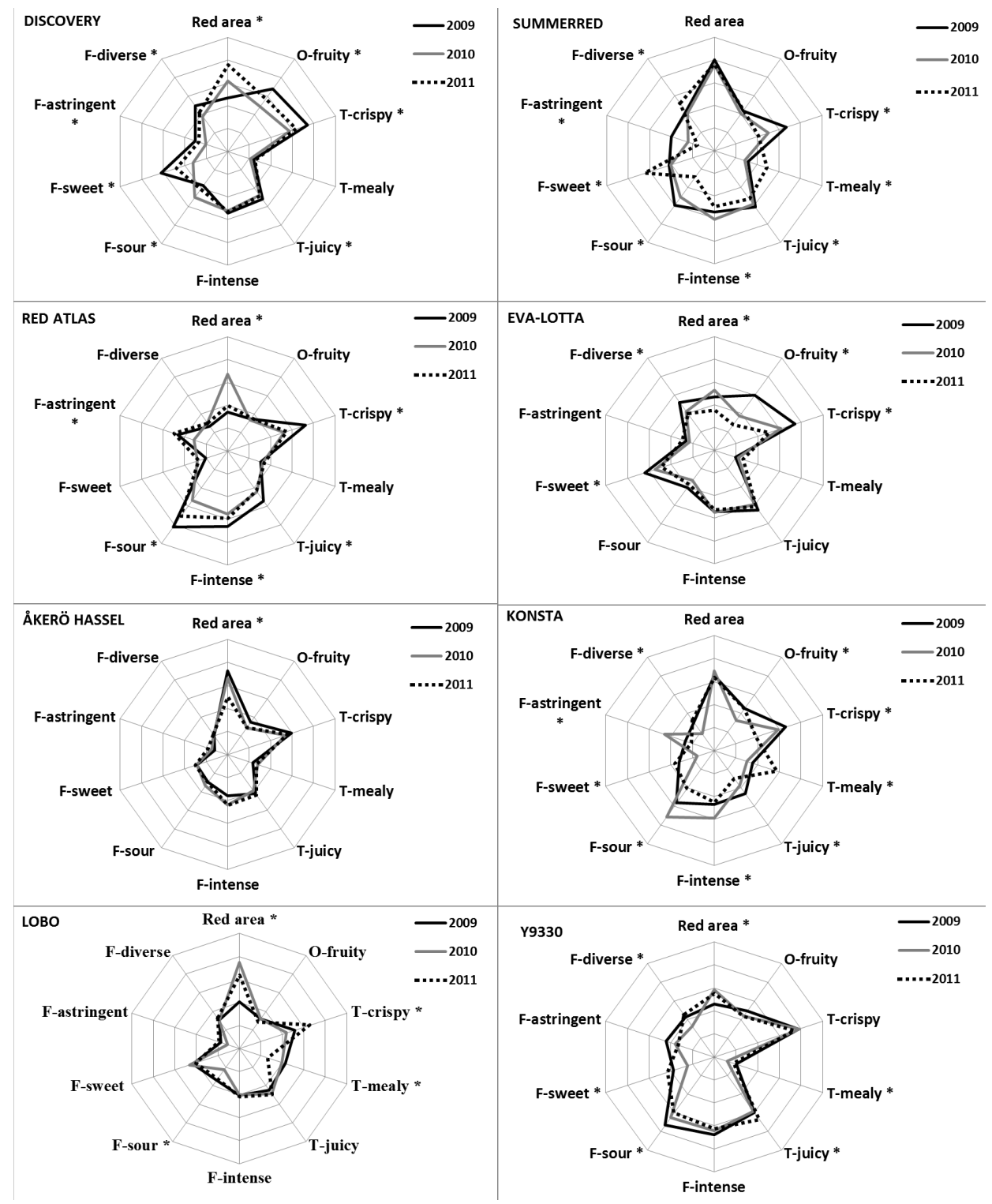

Fig. 3. Profiles of eight autumn and winter cultivars over three harvest years 2009, 2010 and 2011. Prefix $\mathrm{O}$, T or $\mathrm{F}$ before an attribute name denote texture, odour and flavour, respectively; ${ }^{*} p<0.05$ 
'Discovery' and 'Eva-Lotta' were sweeter in the first year than in the next years, while sweetness of 'Summerred' was highest in the third year, 2011. 'Summerred' and 'Konsta' had lower sourness and higher mealiness in 2011 than in the two preceding years. 'Konsta' had a year effect in all attributes except red area, while 'Åkerö Hassel' showed a year effect only in red area, making the latter a promising cultivar for larger production. In general, variation between the years was rather small for 'Eva-Lotta', 'Red-Atlas' and 'Lobo'. Likewise, although 'Y9330' had a year effect in many of the attributes, the effect was small.

'Lobo' is the "mother" tree of four cultivars in Fig. 2, all of which had higher intensity of red colour, fruity odour and flavour intensity than 'Lobo'. In most years, 'Petteri', 'Pekka' and 'Heta' had higher sweetness and flavour intensity than 'Lobo' or their "sibling" 'Tobias'. All except 'Pekka' had juicy and crispy character with minor variation between the years.

\section{Sensory space of the cultivars}

Attribute intensities evaluated in the 17 cultivars are visualised with a PCA graph, which describes the sensory space of the samples and attributes. The first and second principal components (PC) explained $41 \%$ and $27 \%$ of the variance (Fig. 4), while the third PC explained $11 \%$ (result not shown). Texture attributes loaded on the first and third PC's and formed a mealy-juicy-crispy continuum in both. The sour-sweet continuum loaded on the second PC, but had also some loading on the first PC.

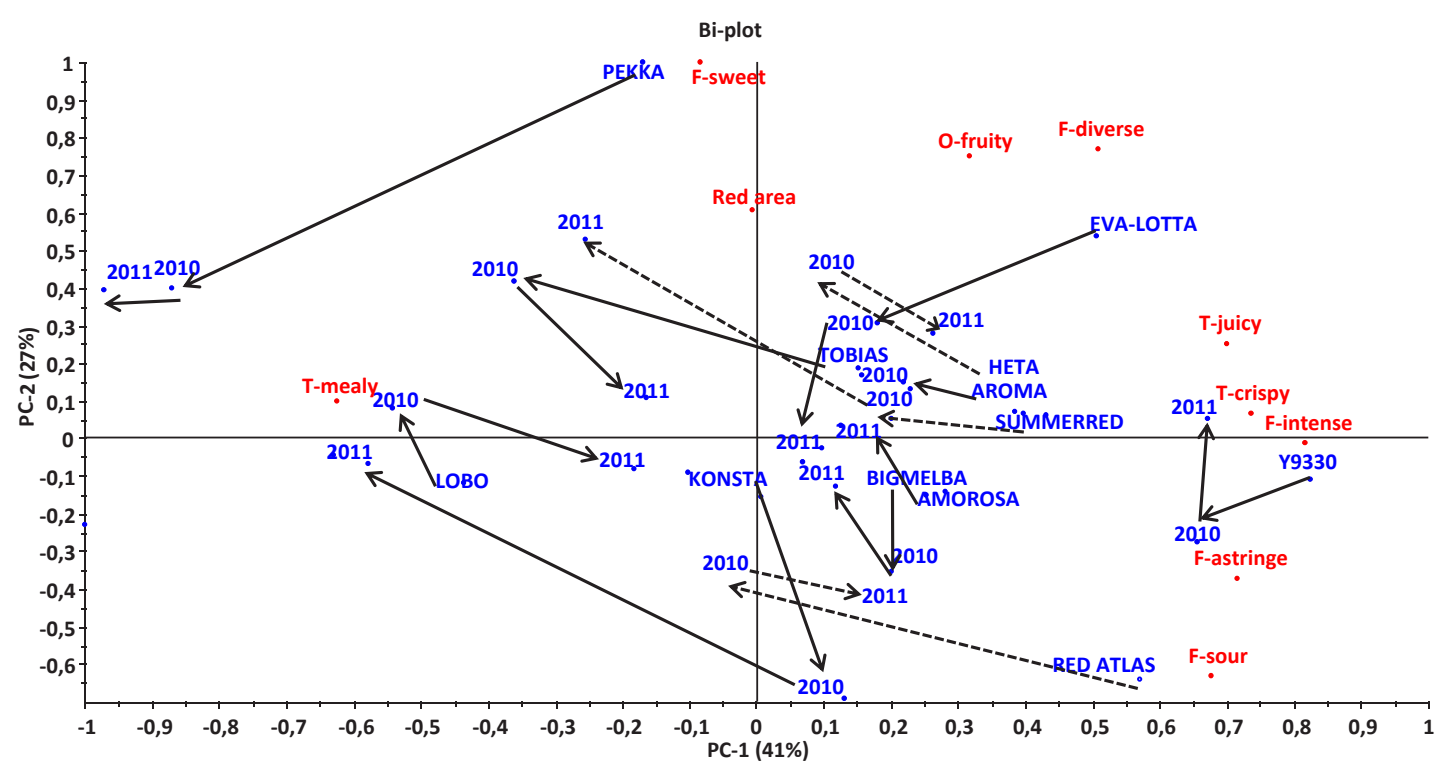

Fig. 4. Apple cultivars over three harvest years visualised with principal component analysis, with the first and second components. Cultivar name denotes year 2009 and the following years are connected with lines and arrows. Dashed lines are used when lines cross. Prefix O, T or F before an attribute name denote texture, odour and flavour, respectively. The graph is based on the data by 17 cultivars, but to demonstrate the overall trends of the cultivars and make the graph easier to study, six cultivars were removed from the graph.

The attributes that are grouped together on the graph have correlation with each other (e.g. juicy and crispy texture and intense flavour). Sour and astringent flavours and flavour intensity are presented on the first PC at the same level with juicy and crispy texture, suggesting that all these attributes are connected. On the high right hand side, fruity odour and diverse flavour are situated together at the approximately same level of the second PC as red area and sweet flavour.

Similarly, cultivars that are grouped near each other are more similar than those that are distant from each other. Juiciness in 'Tobias' or 'Eva-Lotta' was more similar in the second and third year than in the first, when it was the highest. We also notice that juiciness and crispiness of 'Y9330' were quite similar in all the three years. 


\section{Discussion}

The 17 cultivars investigated with sensory analysis in this 3-year-study kept their typical characteristics over the years but showed a year effect in several attributes. For example, 'Red Atlas' and 'Y9330' were always more sour and juicier than 'Lobo', 'Pekka' and 'Tobias', while 'Pekka' was always the mealiest and sweetest cultivar. 'Big Melba', 'Eva-Lotta', 'Aroma'/'Amorosa', 'Y-9330', and to some extent 'Heta', 'Discovery' and 'Lobo' showed a minor year effect. In general, the year effect was fairly large in flavours sour, sweet and astringency, and in crispiness. The year effect on mealiness was smaller than on crispiness (10 and 13 cultivars, respectively). Both these attributes are affected by storage (Seppä et al. 2013a), but not necessary by the harvest year.

For consumers, crispness is an important property and so is a good balance of sweetness and sourness, although individual differences across consumers and cultivars are great in determining a good balance (Harker et al. 2003, Seppä et al. 2013b). In Northern Europe, sourness is usually better accepted than elsewhere (Harker et al. 2003, Bonany et al. 2013). Juiciness, crispiness and low mealiness along with agreeable taste are important indicators of freshness (Peneau et al. 2006, 2007) and key parameters in determining consumer quality. If these characteristics remain stable over the years the cultivar has a promise of success.

Literature confirms that the annual effects on agricultural produce can be manifold and are usually year and cultivar specific (Wolfe et al. 2003, Łata and Tomala 2007, Aprea et al. 2012, Belviso et al. 2013, Guan et al. 2015). Bizjak et al. (2013) concluded that polyphenol content in the apples is strongly dependent upon their growth conditions. Astringency is related to the quantity and quality of phenolic compounds, which are greatly affected by the harvest year (Łata and Tomala 2007, Belviso et al. 2013). Corollaro et al. (2014) showed that astringency is difficult to predict with instrumental data, but it highly correlates with perceived sourness, an association also observed in the present study.

The sensory data by Corollaro et al. (2014), based on evaluation of 27 apple cultivars in Italy, loaded on two PCs. The first PC formed a grainy-juicy-crunchy continuum and the second a sour-sweet continuum, similar to our sensory space of the first and second PCs. The graph by Corollaro et al. (2014) showed some year effect, the magnitude and direction of which varied depending on the cultivar, and thus resembled our results considerably.

In our PCA, texture attributes loaded on the first and third PC and flavour attributes on the first and second PC. The loading pattern resembled the PCA graph extracted from the storage life data in 2010 (Seppä et al. 2013a), which indicated a clear trend towards mealier texture with less flavour intensity during advanced storage time. Our three-year's data shows no clear pattern in that sense. For example, 'Samo', 'Lobo' and 'Tobias' were at their mealiest in 2009 and 2010, 'Vuokko' in 2010 and 'Heta' in 2009 and 2011, but 'Petteri', 'Pekka' and 'Konsta' in 2011. Similarly, the effect of year on crispiness varied in these cultivars. Thus, not even a similar genetic background could explain the effects of harvest year on texture.

Juhnevica-Radenkova et al. (2014), referring to earlier studies, suggested that winter cultivars keep longer as they contain less water compared to summer cultivars. Tukey \& Oran Young (1942) demonstrated that growth pattern of apple fruit is cultivar specific and that early season cultivars increase in size more rapidly than late season cultivars, which could explain why most early season cultivars have short storage life (Tahvonen 2007). Many of the late season domestic cultivars kept well in a study by Seppä et al. (2013a), but not all. Both 'Lobo' and 'Eva-Lotta' developed some quality related issues during long storage, but were relatively stable over the 3-year-study. On the other hand, 'Aroma'/'Amorosa' and 'Y9330' had both long storage life and had only minor differences during the three-year study. This suggests that a long storage life and stable quality over harvest years are not necessarily connected, at least not in all cultivars.

Genes have an important role in the relationship between harvest year and cultivar attribute intensities, but the picture is complicated. Genes regulate many processes in the maturing fruit, such as ethylene emission, which have a vital role in fruit development (e.g. King et al. 2000, Soukoulis et al. 2012). The pattern of volatile accumulation and emission affects fruit quality parameters odour, flavour and texture (Soukoulis et al. 2012). Genes controlling these processes may react differently in varying weather conditions and depending on the cultivar (King et al. 2000, Guan et al. 2015,). Galvez-Lopez et al. (2012) confirmed that the most dominant effects on texture variables were in the descending order: the year of harvest, post-harvest storage duration and genetic factors. Summer 2010 was exceptionally hot and dry and it can be assumed that the apple trees reduced producing flavour compounds in the fruit to ensure survival, and consequently, the flavour profiles of the apples may have suffered (Caprio and Quamme 1999, Tahvonen 2007, Sugiura et al. 2013). The weather in summer 2011 was not ideal either, as it was exceptionally hot and humid. In addition, the spring 2011 was cool and pollination started 
almost a week later than in the two previous years (LUKE 2015b), as for example late season cultivars need DD5 between 190 and 200 to be able to start flowering (Kaukoranta et al. 2010). These climate factors may explain many of the differences in flavour and texture attributes between the first $(2009)$ and the two subsequent years, the year 2009 being quite normal. However, reduced blush due to hot summer, suggested by Sugiura et al. (2013), does not show in our data, as hot summers 2010 and 2011 did not impair red appearance of the cultivars, except perhaps in 'Petteri'. Cultivars may have benefited from the light summer nights in their photosynthesis and other activities related to colour.

When comparing apple data over harvest years, several problems may arise. A fruit may not be from the same orchard each year, or even if it originates from the same source, at least the trees on which it grew are perhaps not the same. In addition, maturity stage during evaluation may vary even if the maturity stage has been monitored carefully. In this study, it is possible that 'Konsta' and 'Summerred' of 2011 were in a more advanced ripeness stage than in the two previous years, as they were considerable more mealy and less sour than before. In addition, when using a human instrument (sensory ratings), the evaluations may shift over time (Lawless and Heymann 2010). The possibility for shifting was even bigger than usually, as the panel composition was not the same from year to year. A strong effort to calibrate and stabilise the instrument was made in annual panel training sessions and by anchoring the rating scales by reference standards. Despite of the measures of precaution, part of the year effect could be due measurement error. However, the yearly effect was not seen in all of the cultivars, and when it was seen, its type and magnitude differed depending on the cultivar and attribute. Thus, we assumed that the observed year effect is largely real. The maturing process in the orchard and consequently, the quality of harvest, is affected by local weather, cultivation practices and post-harvest factors (Hampson et al. 2004, Thybo et al. 2005, Tahvonen 2007, Kader 2008, Kaukoranta et al. 2010). In other words, sensory and nutritional quality of fruits are established on the tree and influenced by orchard environment. In spite of modern horticultural innovations, not much can be done to control the immediate weather conditions to which the trees and the crops are exposed. Thus, it would be beneficial to select cultivars that not only have a favourable consumer quality (Malkki 2007, Kader 2008, Seppä et al. 2013b) but also retain their characteristic sensory quality in a wide spectrum of weather conditions. In this sense, 'Big Melba', 'Discovery', 'Eva-Lotta', 'Aroma'/'Amorosa' and 'Y9330' are good candidates.

\section{Conclusion}

In this study we have examined the relationship of the harvest year, cultivars and their sensory characteristics. We had three research questions to address; what is the effect of harvest year, and if there are effects, are they cultivar-specific, and do early and late season cultivars react differently. We conclude that harvest year has effect on flavour and texture attributes, but their magnitude and direction depend on the cultivar. Late season cultivars appear to be more stable against annual effects, but some early season cultivars may possess the same advantage, as the case of 'Big Melba' shows. More detailed research would be needed to find out the exact effects of weather conditions on the sensory characteristics of the apples and the reasons behind these effects.

\section{Acknowledgements}

The project was funded by the Ministry of Agriculture and Forestry (2887/502/2008). The researchers wish to thank laboratory technician Jutta Varisand and all the panel members for their valuable contribution.

\section{References}

Aprea, E., Corollaro, M.L., Betta, E., Endrizzi, I., Dematte, M.L., Biasioli, F. \& Gasperi, F. 2012. Sensory and instrumental profiling of 18 apple cultivars to investigate the relation between perceived quality and odour and flavour. Food Research International 49: 677-686.

Belviso, S., Scursatone, B., Re, G. \& Zeppa, G. 2013. Novel data on the polyphenol composition of Italian ancient apple cultivars. International Journal of Food Properties 16: 1507-1515.

Bizjak, J., Mikulic-Petkovsek, M., Stampar, F. \& Veberic, R. 2013. Changes in Primary Metabolites and Polyphenols in the Peel of "Braeburn"Apples (Malus domestica Borkh.) during Advanced Maturation. Journal of Agricultural and Food Chemistry 61: 1028310292.

Bonany, J., Buehler, A., Carbo, J., Codarin, S., Donati, F., Echeverria, G., Egger, S., Guerra, W., Hilaire, C., Höller, I., Iglesias, I., Jesionkowska, K., Konopacka, D., Kruczynska, D., Martinelli, A., Pitiot, C., Sansavini, S., Stehr, R. \& Schoorl, F. 2013. Consumer eating quality acceptance of new apple varieties in different European countries. Food Quality and Preference 30: 250-259.

Brookfield, P., Murphy, P., Harker, R. \& MacRae, E. 1997. Starch degradation and starch pattern indices, interpretation and relationship to maturity. Postharvest Biology and Technology 11: 23-30.

Caprio, J.M. \& Quamme, H.A. 1999. Weather conditions associated with apple production in the Okanagan Valley of British Columbia. Canadian Journal of Plant Science 79: 129-137. 
Corollaro, M.L., Aprea, E., Endrizzi, I., Betta, E., Dematte, M.L., Charles, M., Bergamaschi, M., Costa, F., Biasioli, F., Grappadelli, L.C. \& Gasperi, F. 2014. A combined sensory-instrumental tool for apple quality evaluation. Postharvest Biology and Technology 96: 135-144.

Finnish Meteorological Institute 2014. Lämpötila- ja sadetilastoja vuodesta 1961 (Temperature and rainfall statistics from 1961). http://ilmatieteenlaitos.fi/tilastoja-vuodesta-1961.

Finnish Meteorological Institute 2015. DD5 data in South-Western Finland (Kaarina Yltöinen), years 2009-2012. http://ilmatieteenlaitos.fi/.

Galvez-Lopez, D., Laurens, F., Devaux, M.F. \& Lahaye, M. 2012. Texture analysis in an apple progeny through instrumental, sensory and histological phenotyping. Euphytica 185: 171-183.

Guan, Y., Peace, C., Rudell, D., Verma, S. \& Evans, K. 2015. QTLs detected for individual sugars and soluble solids content in apple. Molecular Breeding 35: 1-13.

Hampson, C.R., Quamme, H.A., Kappel, F. \& Brownlee, R.T. 2004. Varying density with constant rectangularity: II. Effects on apple tree yield, fruit size, and fruit color development in three training systems over ten years. HortScience 39: 507-511.

Harker, F.R., Gunson, F.A. \& Jaeger, S.R. 2003. The case for fruit quality: an interpretive review of consumer attitudes, and preferences for apples. Postharvest Biology and Technology 28: 333-347.

Harker, F.R., Marsh, K.B., Young, H., Murray, S.H., Gunso,n F.A. \& Walker, S.B. 2002. Sensory interpretation of instrumental measurements 2: sweet and acid taste of apple fruit. Postharvest Biology and Technology 24: 241-50.

Juhnevica-Radenkova, K., Skudra, L., Skrivele, M., Radenkovs, V. \& Seglina, D. 2014. Impact of the degree of maturity on apple quality during the shelf life. In: FoodBalt Proceedings $9^{\text {th }}$. Baltic Conference on Food Science and Technology Jelgava Latvia. p. 161-166.

Kader, A.A. 2008. Flavor quality of fruits and vegetables. Journal of the Science of Food and Agriculture 88: 1863-1868.

Karlsen, A.M., Aaby, K., Sivertsen, H., Baardseth, P. \& Ellekjær, M.R. 1999. Instrumental and sensory analysis of fresh Norwegian and imported apples. Food Quality and Preference 10: 305-14.

Kaukoranta, T., Tahvonen, R. \& Ylämäki, A. 2010. Climatic potential and risks for apple growing by 2040. Agricultural and Food Science 19: 144-159.

King, G.J., Maliepaard, C., Lynn, J.R., Alston, F.H., Durel, C.E., Evans, K.M., Griffon, B., Laurens, F., Manganaris, A.G., Schrevens, E., Tartarini, S. \& Verhaegh, J. 2000. Quantitative genetic analysis and comparison of physical and sensory descriptors relating to fruit flesh firmness in apple (Malus pumila Mill.). Theoretical and Applied Genetics 100: 1074-1084.

Krannila, A. \& Paalo, A. 2008. Omenapuu. $3^{\text {rd }}$ ed. Helsinki: Multikustannus Oy. 191 p. (in Finnish).

Łata, B. \& Tomala, K. 2007. Apple Peel as a Contributor to Whole Fruit Quantity of Potentially Healthful Bioactive Compounds. Cultivar and Year Implication. Journal of Agricultural and Food Chemistry 55: 10795-10802.

Lawless, H.T. \& Heymann, H. 2010. Sensory evaluation of food. Principles and practices. $2^{\text {nd }}$ ed. New York: Springer. 596 p.

Lehtonen, H. 2015. Evaluating adaptation and the production development of Finnish agriculture in climate and global change. Agricultural and Food Science 24: 219-234.

LUKE 2015a. Cultivation of fruit by ELY Centre in 1984 - 2014. Natural Resources Institute Finland (LUKE), Horticultural Statistics. http://www.maataloustilastot.fi/en/horticultural-statistics-2014_en.

Malkki, S. 2007. Kotimaisen omenan kokonaisvaltainen laatu tarjontaketjussa. Lic thesis. Helsinki: University of Helsinki. 136 p. (in Finnish).

Nummenmaa, L. 2011. Käyttäytymistieteiden tilastolliset menetelmät. Sanoma Pro. 468 p. (in Finnish).

Péneau, S., Brockhoff, P.B., Hoehn, E., Escher, F. \& Nuessli, J. 2007. Relating consumer evaluation of apple freshness to sensory and physico-chemical measurements. Journal of Sensory Studies 22: 313-335.

Péneau, S., Hoehn, E., Roth, H.R., Escher, F. \& Nuessli, J. 2006. Importance and consumer perception of freshness of apples. Food Quality and Preference 17: 9-19.

Railio, J. 2010. Kotimaisten omenien laatu: kesä- ja syyslajikkeiden kuvaukset (Quality of domestic apples: profiles of summer and autumn varieties). EKT-series 1475. Master's thesis. University of Helsinki. 112 p. (in Finnish).

Seppä, L. 2014. Domestic apple cultivars: Sensory descriptions and consumer responses. EKT-series 1633. Dissertation. University of Helsinki. 90 p.

Seppä, L., Railio, J., Mononen, R., Tahvonen, R. \& Tuorila H. 2012. From profiles to practice: Communicating the sensory characteristics of apples to the wider audience through simplified descriptive profiles. LWT- Food Science and Technology 47: 46-55.

Seppä, L., Peltoniemi, A., Tahvonen, R. \& Tuorila H. 2013a. Flavour and texture changes in apple cultivars during storage. LWTFood Science and Technology 54: 500-512.

Seppä, L., Railio, J., Vehkalahti, K., Tahvonen, R. \& Tuorila, H. 2013b. Hedonic responses and individual definitions of an ideal apple as predictors of choice. Journal of Sensory Studies 28: 346-357.

Soukoulis, C., Cappellin, L., Aprea, E., Costa, F., Viola, R., Märk, T.D., Gasperi, F. \& Biasioli, F. 2012. PTR-ToF-MS, a novel, rapid, high sensitivity and non-invasive tool to monitor volatile compound release during fruit post-harvest storage: The case study of apple ripening. Food and Bioprocess Technology 5: 2085-2097.

Sugiura, T., Ogawa, H., Fukuda, N., \& Moriguchi, T. 2013. Changes in the taste and textural attributes of apples in response to climate change. Scientific reports 3: 2418. doi:10.1038/srep02418.

Tahvonen, R. 2007. Omenan viljely. Helsinki: Puutarhaliitto. 246 p. (in Finnish).

Thybo, A.K., Sørensen, L., Christensen, L.P. \& Kühn, B.F. 2005. Quality of apples grown in a Scandinavian high-density orchard and chemical composition in relation to sensory quality. Journal of Horticultural Science and Biotechnology 80: 727-35. 
Tukey, H.B. \& Oran Young J. 1942. Gross morphology and histology of developing fruit of the apple. Botanical Gazette 104: 3-25. van der Sluis, A.A., Dekker, M., de Jager, A. \& Jongen, W.M.F. 2001. Activity and Concentration of Polyphenolic Antioxidants in Apple: Effect of Cultivar, Harvest Year, and Storage Conditions. Journal of Agricultural and Food Chemistry 49: 3606-3613.

Wolfe, K., Wu, X.Z. \& Liu, R.H. 2003. Antioxidant activity of apple peels. Journal of Agricultural and Food Chemistry 51: 609-614. 
Supplemental Tables

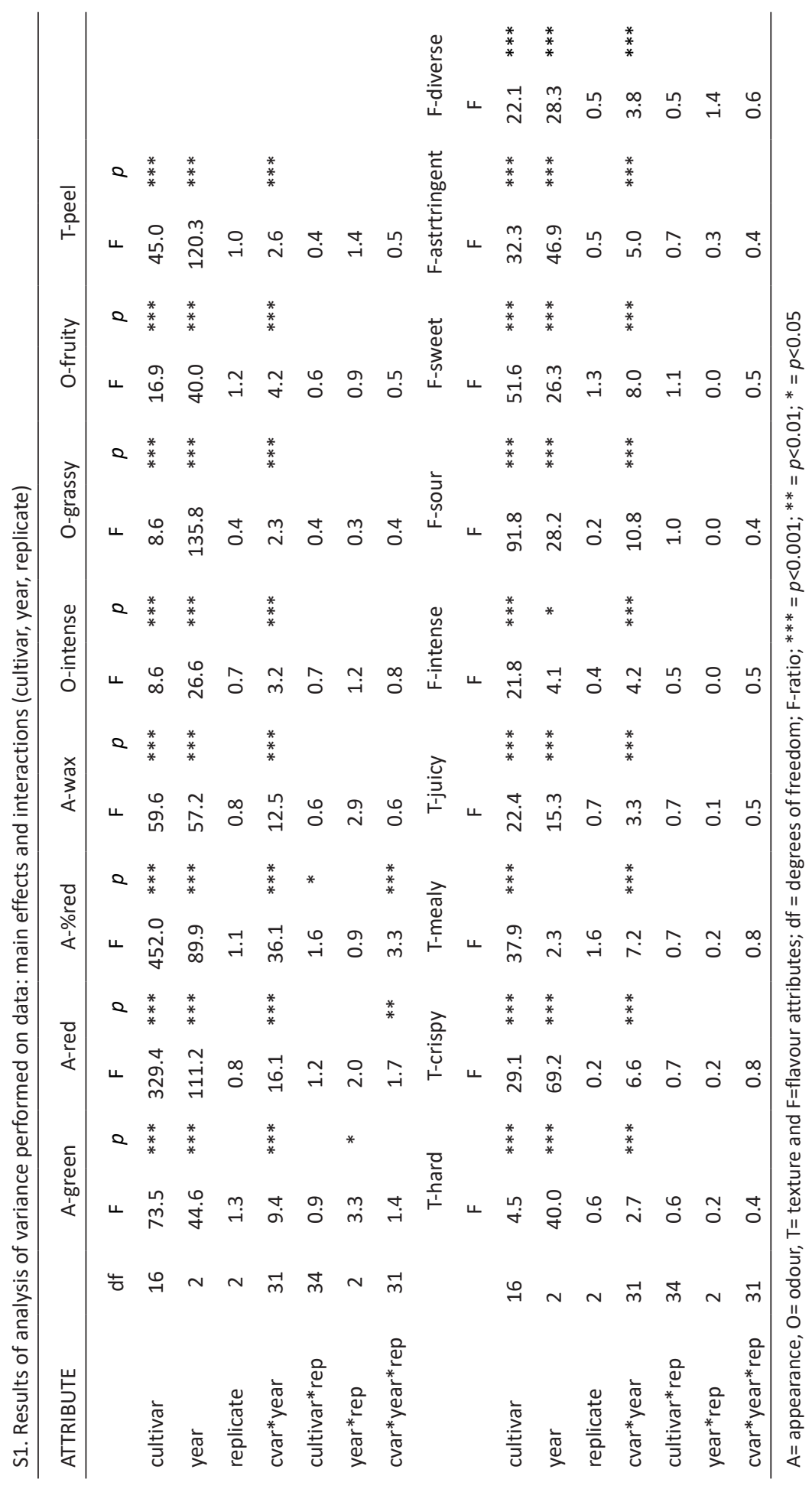


S2. Correlations over $0.3(p<0.001)$ between flavour and texture attributes. Correlations are based on 2870 evaluations of 17 cultivars over three harvest years.

\begin{tabular}{|c|c|c|c|c|c|c|c|}
\hline & T-crispy & T-mealy & T-peel & F-intense & F-sweet & F-astringent & F-diverse \\
\hline T-hard & 0.430 & & 0.373 & & & & \\
\hline T-crispy & 1 & -0.471 & & 0.333 & & & \\
\hline T-juicy & 0.426 & & & 0.340 & & & 0.401 \\
\hline F-intense & & & & 1 & & & 0.481 \\
\hline F-sour & & & & 0.435 & 0.342 & 0.595 & \\
\hline F-sweet & & & & & 1 & & 0.571 \\
\hline
\end{tabular}


S3. Attribute intensity mean ratings in descriptive analysis of each cultivar during the three harvest years. The number before the cultivar name denotes the harvest year, $1=2009,2=2010$ and $3=2011$. Letters $\mathrm{O}, \mathrm{T}$ and F denote odour, texture and flavour, respectively.

\begin{tabular}{|c|c|c|c|c|c|c|c|c|c|c|c|}
\hline Sample & $n$ (tot) & $\begin{array}{l}\text { Red } \\
\text { area }\end{array}$ & O-fruity & T-crispy & T-mealy & T-juicy & F-intense & F-sour & F-sweet & F-astringent & F-diverse \\
\hline 1-PIRJA & 48 & 4.5 & 5.2 & $4.0 \mathrm{~b}$ & 5.9 & 5.1 & 4.4 & 3.3 & $5.3 b$ & $2.4 \mathrm{~b}$ & $4.0 \mathrm{~b}$ \\
\hline 3-PIRJA & 26 & 4.9 & 4.1 & $3.1 \mathrm{a}$ & 6.3 & 5.0 & 4.3 & 3.1 & $3.5 a$ & $1.2 \mathrm{a}$ & $2.9 a$ \\
\hline 1-VUOKKO & 48 & $1.4 \mathrm{~b}$ & 3.8 & $5.2 b$ & $4.7 b$ & $5.2 b$ & $4.4 a b$ & $3.2 b$ & 5.3 & $1.7 \mathrm{~b}$ & $4.3 b$ \\
\hline 2-VUOKKO & 56 & $0.5 a$ & 2.9 & $2.9 a$ & $5.4 b$ & $3.4 a$ & $3.5 a$ & $1.8 a$ & 4.3 & $0.7 a$ & $2.6 a$ \\
\hline 3-VUOKKO & 26 & $1.2 \mathrm{~b}$ & 3.0 & $5.5 b$ & $3.0 \mathrm{a}$ & $5.4 b$ & $4.9 \mathrm{~b}$ & $3.9 b$ & 4.7 & $1.5 a b$ & $4.0 \mathrm{~b}$ \\
\hline 1-PETTERI & 48 & $8.8 \mathrm{c}$ & $5.9 b$ & $6.5 b$ & $3.4 a$ & $6.7 b$ & $7.2 \mathrm{~b}$ & 5.5 & $5.7 b$ & $5.6 \mathrm{~b}$ & $6.8 \mathrm{c}$ \\
\hline 2-PETTERI & 56 & $6.4 a$ & $3.4 a$ & $4.6 a$ & $3.3 a$ & $4.5 a$ & $5.2 a$ & 4.8 & $3.3 a$ & $3.0 a$ & $3.6 a$ \\
\hline 3-PETTERI & 26 & $7.6 b$ & $4.4 a$ & $4.9 a$ & $4.5 b$ & $5.4 a$ & $6.5 b$ & 5.4 & $4.0 a$ & $3.1 \mathrm{a}$ & $5.0 \mathrm{~b}$ \\
\hline 1-BIG MELBA & 96 & 3.4 & 4.5 & 5.6 & $4.2 a$ & 5.3 & 5.4 & 5.7ab & $4.2 \mathrm{~b}$ & $5.2 \mathrm{~b}$ & 3.9 \\
\hline 2-BIG MELBA & 56 & 2.9 & 3.9 & 5.2 & $2.8 a$ & 4.7 & 5.9 & $5.8 b$ & $3.1 a$ & 4.1ab & 3.5 \\
\hline 3-BIG MELBA & 52 & 3.4 & 4.3 & 5.4 & $3.1 b$ & 5.0 & 5.2 & $4.9 a$ & $4.1 \mathrm{~b}$ & $3.7 a$ & 3.7 \\
\hline 1-SAMO & 96 & 0.7 & 3.3 & $4.6 b$ & $5.5 b$ & $4.6 b$ & $5.3 a b$ & $6.6 b$ & 2.8 & $4.3 b$ & 3.2 \\
\hline 2-SAMO & 56 & 0.8 & 3.4 & $3.1 a$ & $5.9 b$ & $3.6 a$ & $4.5 a$ & $4.5 a$ & 2.8 & $2.2 a$ & 2.6 \\
\hline 3-SAMO & 52 & 0.6 & 3.2 & $5.4 b$ & $3.1 a$ & $5.1 b$ & $5.9 b$ & $6.8 \mathrm{~b}$ & 2.9 & $3.3 a$ & 3.3 \\
\hline 1-HETA & 96 & $4.6 a$ & 4.9 & 6.0 & $3.5 b$ & $5.9 b$ & $5.7 a$ & $5.2 \mathrm{~b}$ & $4.4 a$ & $4.3 b$ & 4.5 \\
\hline 2-HETA & 56 & $7.0 \mathrm{~b}$ & 4.0 & 5.5 & $2.4 a$ & $5.8 \mathrm{~b}$ & $5.3 a$ & $3.0 a$ & $5.5 b$ & $2.1 a$ & 4.6 \\
\hline 3-HETA & 52 & $9.0 c$ & 4.0 & 5.5 & $3.6 b$ & $4.9 a$ & $6.6 b$ & $5.2 \mathrm{~b}$ & $5.3 b$ & $2.9 a$ & 5.3 \\
\hline 1-PEKKA & 96 & 9.2 & $6.6 c$ & $6.5 b$ & $4.5 a$ & 3.8 & $5.7 b$ & 1.1 & $8.2 b$ & $1.0 \mathrm{~b}$ & $5.3 b$ \\
\hline 2-PEKKA & 56 & 9.4 & $3.6 a$ & $4.3 a$ & $4.9 a$ & 3.9 & $3.5 a$ & 0.9 & $6.5 a$ & $0.4 a$ & $3.0 a$ \\
\hline 3-PEKKA & 52 & 8.9 & $4.6 b$ & $3.5 a$ & $6.3 b$ & 3.4 & $3.9 a$ & 0.9 & $6.1 a$ & $0.6 a$ & $2.7 a$ \\
\hline 1-TOBIAS & 96 & $6.5 a$ & $5.2 b$ & $5.5 b$ & 4.3 & $5.8 b$ & 5.1 & $4.7 b$ & $4.6 a$ & $3.9 c$ & 4.1 \\
\hline 2-TOBIAS & 56 & $8.2 b$ & $4.8 \mathrm{ab}$ & $4.2 a$ & 4.3 & $4.7 a$ & 4.9 & $2.4 a$ & $5.8 \mathrm{~b}$ & $1.4 a$ & 3.9 \\
\hline 3-TOBIAS & 52 & $8.2 b$ & $4.2 \mathrm{a}$ & $5.2 \mathrm{~b}$ & 3.7 & $4.8 a$ & 4.9 & $3.9 b$ & $4.5 a$ & $2.3 b$ & 3.4 \\
\hline 1-DISCOVERY & 96 & $4.7 a$ & $6.8 c$ & $7.4 \mathrm{~b}$ & 2.4 & $5.2 b$ & 5.4 & $3.7 a$ & $6.2 \mathrm{c}$ & $3.0 \mathrm{~b}$ & $4.9 \mathrm{~b}$ \\
\hline 2-DISCOVERY & 56 & $6.2 b$ & $4.8 a$ & $5.7 a$ & 2.1 & $4.8 a$ & 5.2 & $5.0 \mathrm{~b}$ & $3.3 a$ & $2.0 a$ & $3.8 a$ \\
\hline 3-DISCOVERY & 52 & $7.6 c$ & $5.7 b$ & $6.3 a$ & 2.5 & $4.9 a$ & 5.3 & 4.1ab & $4.8 b$ & $2.7 a$ & 4.3ab \\
\hline 1-SUMMER RED & 96 & 8.0 & 4.3 & $6.7 c$ & $3.2 \mathrm{a}$ & $6.2 \mathrm{~b}$ & $5.4 a b$ & $5.9 c$ & $4.2 \mathrm{a}$ & $4.0 \mathrm{~b}$ & $4.3 a$ \\
\hline 2-SUMMER RED & 56 & 7.6 & 4.0 & $5.0 \mathrm{~b}$ & $2.8 a$ & $5.8 a b$ & $6.1 \mathrm{~b}$ & $5.1 b$ & $4.0 \mathrm{a}$ & $2.4 a$ & $4.1 \mathrm{a}$ \\
\hline 3-SUMMER RED & 52 & 7.6 & 4.4 & $4.1 a$ & $4.9 b$ & $5.3 a$ & $4.9 a$ & $2.9 a$ & $6.5 b$ & $1.6 a$ & $5.1 b$ \\
\hline 1-REDATLAS & 44 & $3.4 a$ & 3.4 & $7.3 b$ & 3.1 & $5.4 b$ & $6.6 b$ & $8.2 \mathrm{c}$ & 2.0 & $4.6 \mathrm{~b}$ & 2.7 \\
\hline 2-REDATLAS & 56 & $6.7 b$ & 3.3 & $5.2 a$ & 3.3 & $4.4 a$ & $5.5 a$ & $5.3 a$ & 2.8 & $3.1 a$ & 3.0 \\
\hline 3-REDATLAS & 52 & $3.9 a$ & 3.6 & $5.5 a$ & 3.4 & $4.3 a$ & $5.9 a b$ & $7.0 \mathrm{~b}$ & 2.7 & $5.0 \mathrm{~b}$ & 3.0 \\
\hline 1-EVA-LOTTA & 44 & $4.7 b$ & 6.0 & $7.4 c$ & 2.0 & 6.5 & 5.5 & 4.1 & $6.4 b$ & 2.6 & $5.2 b$ \\
\hline 2-EVA-LOTTA & 56 & $5.3 b$ & 3.7 & $6.1 b$ & 2.2 & 5.9 & 5.5 & 3.3 & $5.5 a$ & 2.3 & $4.2 \mathrm{a}$ \\
\hline 3-EVA-LOTTA & 52 & $3.5 a$ & 2.8 & $5.0 \mathrm{a}$ & 2.6 & 6.2 & 5.2 & 3.8 & $4.9 a$ & 2.9 & $4.0 a$ \\
\hline $\begin{array}{l}\text { 1-ÅKERÖ } \\
\text { HASSEL }\end{array}$ & 44 & $7.2 \mathrm{~b}$ & 3.5 & 6.0 & 2.3 & 4.2 & 3.6 & 3.0 & 2.9 & 1.2 & 2.1 \\
\hline $\begin{array}{l}\text { 2-ÅKERÖ } \\
\text { HASSEL }\end{array}$ & 56 & $6.6 b$ & 2.8 & 5.4 & 2.8 & 3.0 & 4.4 & 3.3 & 2.9 & 1.5 & 2.1 \\
\hline $\begin{array}{l}\text { 3-ÅKERÖ } \\
\text { HASSEL }\end{array}$ & 52 & $5.0 \mathrm{a}$ & 2.9 & 5.5 & 2.7 & 4.4 & 4.4 & 3.0 & 3.0 & 1.8 & 2.1 \\
\hline
\end{tabular}


S3 continues:

\begin{tabular}{|c|c|c|c|c|c|c|c|c|c|c|c|}
\hline Sample & $\mathrm{n}$ (tot) & $\begin{array}{l}\text { Red } \\
\text { area }\end{array}$ & O-fruity & T-crispy & T-mealy & T-juicy & F-intense & F-sour & F-sweet & F-astringent & F-diverse \\
\hline 1-KONSTA & 44 & 6.5 & $4.5 b$ & $6.6 b$ & 3.5a & $4.6 \mathrm{~b}$ & $4.7 a$ & $5.6 b$ & $3.2 b$ & $2.6 a$ & $3.0 \mathrm{~b}$ \\
\hline 2-KONSTA & 56 & 6.9 & $3.2 \mathrm{a}$ & $5.9 b$ & 3.0a & $3.8 \mathrm{ab}$ & $5.9 b$ & $7.1 \mathrm{c}$ & $1.0 \mathrm{a}$ & $4.6 \mathrm{~b}$ & $1.8 \mathrm{a}$ \\
\hline 3-KONSTA & 52 & 6.3 & $4.5 b$ & $3.8 \mathrm{a}$ & $5.7 b$ & $3.0 \mathrm{~b}$ & $4.5 a$ & $4.1 \mathrm{a}$ & $3.6 \mathrm{~b}$ & $2.1 \mathrm{a}$ & $3.3 b$ \\
\hline 1-LOBO & 44 & $4.1 \mathrm{a}$ & 3.2 & $5.2 \mathrm{a}$ & $4.3 b$ & 4.5 & 4.1 & $3.4 \mathrm{~b}$ & 4.3 & 1.7 & 3.1 \\
\hline 2-LOBO & 56 & $7.5 c$ & 3.2 & $4.4 a$ & $3.9 b$ & 4.9 & 4.0 & $2.3 a$ & 4.6 & 1.1 & 3.0 \\
\hline 3-LOBO & 52 & $6.4 b$ & 2.8 & $6.6 b$ & $2.6 a$ & 4.9 & 4.2 & $3.3 b$ & 4.1 & 1.9 & 3.3 \\
\hline 1-AMOROSA & 44 & $3.9 a$ & 3.3 & $7.2 \mathrm{ab}$ & 2.5 & 5.1 & 5.4 & $5.5 b$ & $4.5 a b$ & $3.2 b$ & 4.0 \\
\hline 1-AROMA & 44 & $4.5 a$ & 3.5 & $7.7 b$ & 2.2 & 5.8 & 5.6 & $4.9 a b$ & $5.3 b$ & $2.7 a b$ & 4.4 \\
\hline 2-AROMA & 56 & $7.4 c$ & 3.9 & $6.4 a$ & 2.4 & 5.7 & 5.6 & $4.2 \mathrm{a}$ & $4.4 a b$ & $2.2 a b$ & 4.4 \\
\hline 3-AMOROSA & 52 & $5.3 b$ & 4.3 & $6.4 a$ & 2.7 & 5.5 & 5.2 & $4.4 a$ & $4.0 \mathrm{a}$ & $2.1 \mathrm{a}$ & 3.9 \\
\hline $1-Ү 9330$ & 44 & 4.6a & 4.9 & 7.8 & $2.0 \mathrm{~b}$ & $6.0 a b$ & 6.8 & $7.3 b$ & $3.8 \mathrm{~b}$ & 4.4 & $4.3 b$ \\
\hline $2-Y 9330$ & 56 & $5.8 b$ & 4.4 & 7.8 & $1.2 \mathrm{a}$ & $5.8 a$ & 6.4 & $6.5 a b$ & $2.4 a$ & 3.6 & $3.3 a$ \\
\hline 3-Ү9330 & 52 & $5.5 b$ & 4.3 & 7.4 & 1.8ab & $6.7 b$ & 6.2 & $6.0 \mathrm{a}$ & $4.3 b$ & 3.3 & $4.5 b$ \\
\hline
\end{tabular}

